\title{
PROSES RECOVERY DAN PENGKONSENTRASIAN PROTEIN AIR PEREBUSAN PINDANG TONGKOL (Euthynnus affinis) MELALUI ULTRAFILTRASI
}

\section{RECOVERY PROCESS AND CONCENTRATION OF DRINKING WATER PROTEIN "PINDANG TONGKOL" (Euthynnus affinis) THROUGH ULTRAFILTRATION}

\author{
Uju*), Bambang Riyanto, Bustami Ibrahim, Wahyu Ramadhan, Irfan Setia Tanjung \\ Departemen Teknologi Hasil Perairan, Fakultas Perikanan dan Ilmu Kelautan, Institut Pertanian Bogor \\ Kampus IPB Darmaga, Jalan Agatis, Bogor 16680, Jawa Barat, Indonesia \\ Email: ujusadi@gmail.com
}

Makalah: Diterima 18 September 2017; Diperbaiki 11 Desember 2017; Disetujui 29 Desember 2017

\begin{abstract}
"Pindang" is a fisheries product which is produced by combination of boiling and salting. Boiling in a salt solution causes dissolving protein into the boiling water. Membrane process has been applied for the concentrating of protein. In this study, the characterization and recovery of protein from the boiled water of "pindang" were carried out using 0.05 um ultrafiltration membrane. The parameters of study included the effect of the concentration factor on the protein concentration, flux of permeate, and protein rejection coefficient. The concentrating of "pindang" boiling water using $0.05 \mu \mathrm{m}$ ultrafiltration membrane increased $46.75 \%$ of protein. During ultrafiltration concentrating process, flux decreased from $6.58 \mathrm{~L}^{2} \mathrm{~h}$ at the beginning of the concentration to $2.71 \mathrm{~L}^{2} \mathrm{~m}^{2} \mathrm{~h}$ at fortieth minute. Rejection coefficient increased from $41.2 \%$ at the beginning of the concentrating to $55.07 \%$ at fortieth minute. The decreasing values of the parameters COD, TSS, turbidity, protein, and fat were higher than the decreasing of TDS, salinity, and $p H$. The dominant molecular weight of protein in protein concentrate of "pindang" boiling water was $33.45 \mathrm{kDa}$.
\end{abstract}

Keywords: protein concentrate, "pindang", ultrafiltration

\section{ABSTRAK}

Pindang merupakan hasil olahan ikan dengan cara kombinasi perebusan dan penggaraman. Perebusan dalam larutan garam menyebabkan terlarutnya protein kedalam air perebusan. Dalam penelitian ini dikaji karakterisasi dan recovery protein dari air rebusan pindang menggunakan ultrafiltrasi $0,05 \mu \mathrm{m}$. Kajian proses meliputi pengaruh faktor konsentrasi terhadap konsentrasi protein dan fluks, dan koefisien rejeksi protein selama pengkonsentrasian. Proses recovery dan pengkonsentrasian air perebusan pindang denganultrafiltrasi $0,05 \mu \mathrm{m}$ dapat meningkatkan konsentrasi protein $46,75 \%$. Selama pengkonsentrasian menyebabkan nilai fluks mengalami penurunan dari $6,58 \mathrm{~L} / \mathrm{m}^{2}$ jam pada awal pengkonsentrasian menjadi $2,71 \mathrm{~L} / \mathrm{m}^{2} \mathrm{jam}$ pada menit ke-40. Koefisien rejeksi selama pengkonsentrasian mengalami peningkatan dari 41,2\% pada awal pengkonsentrasian menjadi $55,07 \%$ pada menit ke-40. Nilai penurunan parameter COD, TSS, kekeruhan, protein, dan lemak lebih tinggi dibandingkan penurunan TDS, salinitas, dan $\mathrm{pH}$. Berat molekul protein yang dominan pada konsentrat protein air perebusan pindang adalah $33,45 \mathrm{kDa}$.

Kata kunci: konsentrat protein, pindang, ultrafiltrasi

\section{PENDAHULUAN}

Pindang menempati urutan kedua volume produksi olahan hasil perikanan Indonesia setelah ikan kering/asin dengan total produksi mencapai 229.566 ton pada tahun 2015 (KKP, 2016). Tingginya volume produksi pindang diikuti pula oleh besarnya volume air perebusan yang dihasilkan dari pemindangan. Sebanyak $500 \mathrm{~L}$ air perebusan pindang diperkirakan dapat dihasilkan pada produksi satu ton pindang. Perebusan dalam larutan garam memungkinkan terlarutnya protein kedalam air perebusan sehingga mengurangi kandungan protein dalam bahan. Niamnuy et al. (2008) melaporkan bahwa larutan garam dapat mengakibatkan terlarutnya protein ke dalam air perebusan. Konsentrasi protein yang larut ke dalam air perebusan berbanding lurus dengan konsentrasi garam dan waktu perebusan. Besarnya penurunan jumlah protein yang terlarut akibat perebusan dalam larutan garam dapat mencapai $66 \%$ dari total protein pada udang.

Air perebusan pindang selama ini merupakan hasil samping pemindangan yang belum banyak dimanfaatkan. Sebagian besar unit pengolahan pindang membuang air perebusan tanpa ada proses pengolahan ulang, sehingga berpotensi mencemari lingkungan. Pemanfaatan air perebusan pindang yang telah dilakukan diantaranya adalah sebagai bahan baku pembuatan petis ikan. Menurut Fitriyani et al. (2013) petis ikan diperoleh dari air perebusan pindang ditambah beberapa bahan lain kemudian dikentalkan dengan cara dipanaskan sehingga kadar airnya berkurang dan viskositasnya 
menjadi tinggi. Pengkonsentratan air rebusan pindang dengan pemanasan selain memerlukan energi tinggi karena menguapkan sejumlah air juga dapat menyebabkan kerusakan pada komponen gizinya karena panas yang tinggi dan waktu yang lama.

Metode pemisahan dan pengkonsentrasian yang umum dan telah banyak diterapkan diantaranya menggunakan adsorpsi (Shukoor et al., 2007), presipitasi (Kurinomaru et al., 2014), evaporasi (Schuck et al., 2015), dan membran reverse osmosis (Uju et al., 2009). Diantara metode tersebut, ultrafiltrasi memiliki keunggulan pada isolasi dan pemisahan protein karena tidak memerlukan banyak garam dan buffer, dapat berjalan terus-menerus, dan menghilangkan komponen pengotor (Kumar dan Lawler, 2014). Proses membran menjaga kualitas senyawa terkonsentrasi dibandingkan dengan proses panas atau proses kimia karena dilakukan pada temperatur relative rendah (Dumay et al., 2008). Schuck et al. (2015) melaporkan bahwa untuk memisahkan $1 \mathrm{~kg}$ air pada susu menggunakan evaporasi memerlukan energi $418 \mathrm{~kJ}$. Masse et al. (2011) melaporkan bahwa untuk memisahkan air pada proses pretreatment desalinasi air laut menggunakan membran ultrafiltrasi membutuhkan energi sebesar $0,5 \mathrm{~kJ}$ untuk setiap $1 \mathrm{~kg}$ air yang dipisahkan. Pengkonsentrasian menggunakan membran tidak mengakibatkan perubahan fase bahan seperti yang terjadi pada evaporasi sehingga membutuhkan energi yang lebih sedikit. Berdasarkan penjelasan di atas penggunaan membran dalam pemisahan dan pengkonsentrasian protein dapat menghemat penggunaan energi dan bahan kimia.

Teknologi membran telah banyak diaplikasikan untuk pemisahan protein dalam suatu larutan. Menurut Guo et al. (2009) aplikasi membran ultrafiltrasi untuk mengolah air limbah dapat diterima secara luas karena secara konsisten menghasilkan kualitas air buangan lebih baik dan mengembalikan komponen yang masih berharga untuk daur ulang maupun dijual. Benhabiles et al. (2013) melaporkan bahwa membran ultrafiltrasi dengan ukuran pori $0,05 \mu \mathrm{m}$ dapat memisahkan protein hasil proses deproteinisasi pembuatan kitin yang mencapai 97\%. Gringer et al. (2015) melaporkan bahwa membran ultrafiltrasi dengan rata-rata ukuran pori $0,04 \mu \mathrm{m}$ berhasil mereduksi kandungan protein pada marinade hingga $76 \%$.

Pengolahan air perebusan pindang menggunakan membran ultrafiltrasi diharapkan dapat memisahkan protein dengan sedikit kerusakan. Proses tersebut akan menghasilkan air garam yang dapat digunakan kembali untuk perebusan pindang, karena membran ultrafiltrasi masih meloloskan garam (Cheryan, 1998). Penelitian recovery protein air perebusan pindang menggunakan membran ultrafiltrasi menjadi penting untuk dilakukan. Penelitian ini bertujuan untuk menentukan pengaruh penggunaan membran ultrafiltrasi untuk recovery protein dari air perebusan pindang, menguji kualitas protein dan air hasil pengolahan.

\section{BAHAN DAN METODE}

\section{Bahan dan Alat}

Sampel yang digunakan merupakan air sisa proses perebusan pindang ikan tongkol (Euthynnus affinis) dari UKM Cindy Group, Parung-Bogor. Bahan-bahan yang digunakan dalam analisis protein antara lain comassie briliant blue G-250(SIGMA), asam fosfat $85 \%$, etanol 95\%, dan Bovine Serum Albumin (SIGMA). Bahan-bahan yang digunakan untuk analisis kualitas air antara lain $\mathrm{H}_{2} \mathrm{SO}_{4} \cdot \mathrm{Ag}_{2} \mathrm{SO}_{4}$, digestion solution, buffer fosfat, $\mathrm{MgSO}_{4}, \mathrm{CaCl}_{2}$, $\mathrm{FeCl}_{3}, \mathrm{MnSO}_{4} 1,25 \mathrm{~N}, \mathrm{NaOH}+\mathrm{KI}, \mathrm{H}_{2} \mathrm{SO}_{4}$ pekat, $\mathrm{Na}_{2} \mathrm{~S}_{2} \mathrm{O}_{3}$, dan indikator kanji. Bahan untuk analisis lemak diantaranya klorometanol dan $\mathrm{MgCl}_{2}$. Bahanbahan untuk analisis berat molekul protein antara lain marker Spectra Multicolor Broad Range Protein Ladder dari Thermo Scientific, buffer sampel, pewarna silver staining, larutan fiksasi, etanol 20\%, $\mathrm{Na}_{2} \mathrm{CO}_{3}, \mathrm{Na}_{2} \mathrm{~S}_{2} \mathrm{O}_{3}, \mathrm{AgNO}_{3}$, larutan developing gel, stop solution, dan air bebas ion.

Alat-alat utama yang digunakan dalam penelitian ini adalah membran hollow fibre ultrafiltrasi berbahan polipropilen dengan rata-rata ukuran pori $0,05 \mu \mathrm{m}$ (setara dengan molecular weight cutoff (MWCO) $50 \mathrm{kDa}$ ) dan luas permukaan membran 1,8 $\mathrm{m}^{2}$ (GDP Filter, Bandung) dengan pompa penggerak Deng Yuan KJ-2600. Alat-alat yang digunakan untuk analisis uji kualitas air adalah COD reaktor, $\mathrm{pH}$ meterThermo Scientific ORION 3 STAR, multimeter HACH Sension5, turbidimeter HACH 2100Q, dan spectrophotometerHACH $D R / 2000$. Analisis konsentrasi protein total menggunakan alat $U V$-Vis $R S$ Spectrophotometer $U V-2500$ dari Labomed. Analisis berat molekul protein menggunakan alat TOMY MRX-152 High Speed Refrigerated Micro Centrifuge dan Hoefer Scientific InstrumentsPS 500XT DCPower Supply.

\section{Metode Penelitian}

Tahapan penelitian dibagi kedalam 3tahapan, yaitu (1) sampling dan karakterisasi air rebusan pindang, (2) pengkonsentratan air rebusan pindang, dan (3) karakterisasi konsentrat air rebusan pindang. Diagram alir prosedur penelitian dapat dilihat pada Gambar 1.

\section{Sampling dan Karakterisasi Air Perebusan Pindang}

Sampling dilakukan ketika proses produksi pindang telah selesai yaitu air rebusan dalam keadaan masih panas dan segar. Setelah suhunya dingin, sampel selanjutnya dibawa dalam kemasan berpendingin (cool box) dengan penambahan es curai untuk sampel dikarakterisasi di laboratorium. Parameter uji karakterisasi meliputi kadar protein, kadar lemak, dan berat molekul protein, kekeruhan, 
$\mathrm{pH}$, total dissolved solids (TDS), chemical oxygen demand (COD), total suspended solids (TSS), dan salinitas.

\section{Pengkonsentratan Protein Air Perebusan Pindang}

Sebanyak 5L air rebusan pindang dimasukkan kedalam tangki umpan. Proses pengkonsentrasian atau pemekatan dengan ultrafiltrasi dilakukan dengan cara mengalirkan air rebusan pindang melalui membran ultrafiltrasi oleh pompa pada tekanan transmembran 0,5 bar pada suhu ruang $\left( \pm 30^{\circ} \mathrm{C}\right)$. Fraksi permeat yaitu fraksi yang lolos membran dipisahkan dan ditampung dalam wadah khusus, sedangkan retentat (fraksi yang tidak lolos membran) dialirkan kembali ke tangki umpan. Proses ini mengakibatkan peningkatan konsentrasi terlarut (konsentrat) pada tangki umpan yang semakin pekat seiring dengan waktu pemekatan berlangsung. Skema pengkonsentrasian air rebusan pindang disajikan pada Gambar 2. Parameter kinerja proses ultrafiltrasi adalah faktor konsentrasi (Krijgsman, 1992), fluks (Cheryan, 1998), dan koefisien rejeksi (Benhabiles et al., 2013).

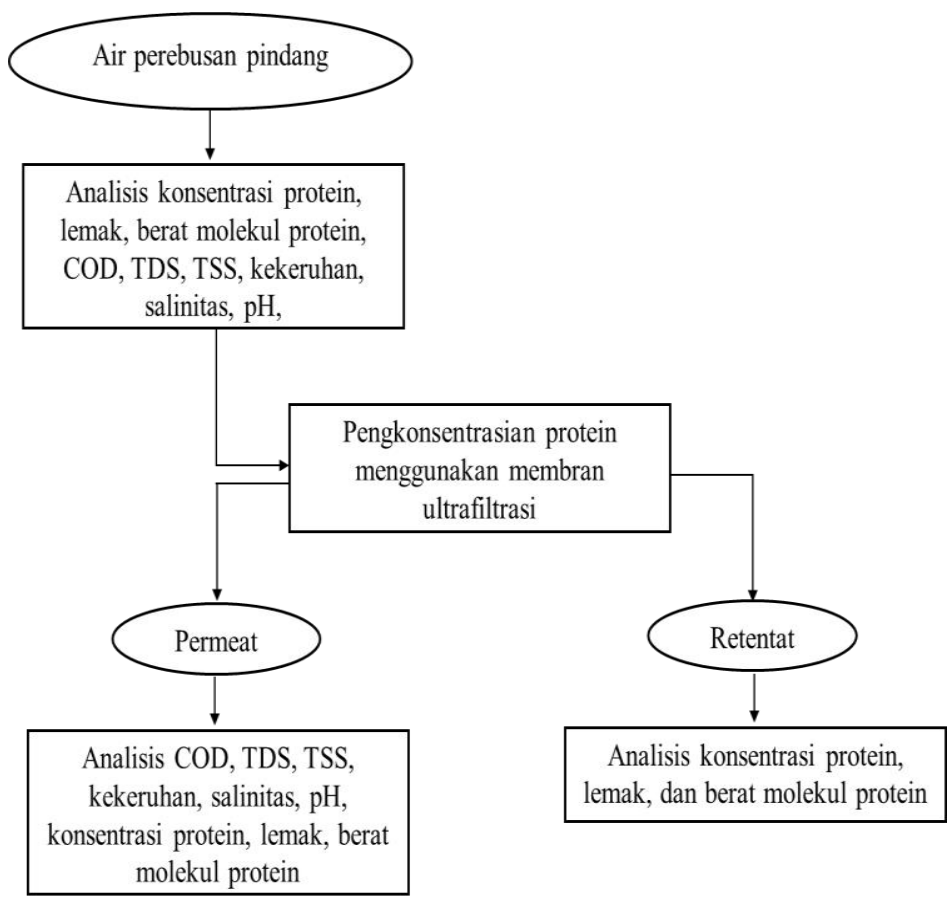

Gambar 1. Prosedur penelitian

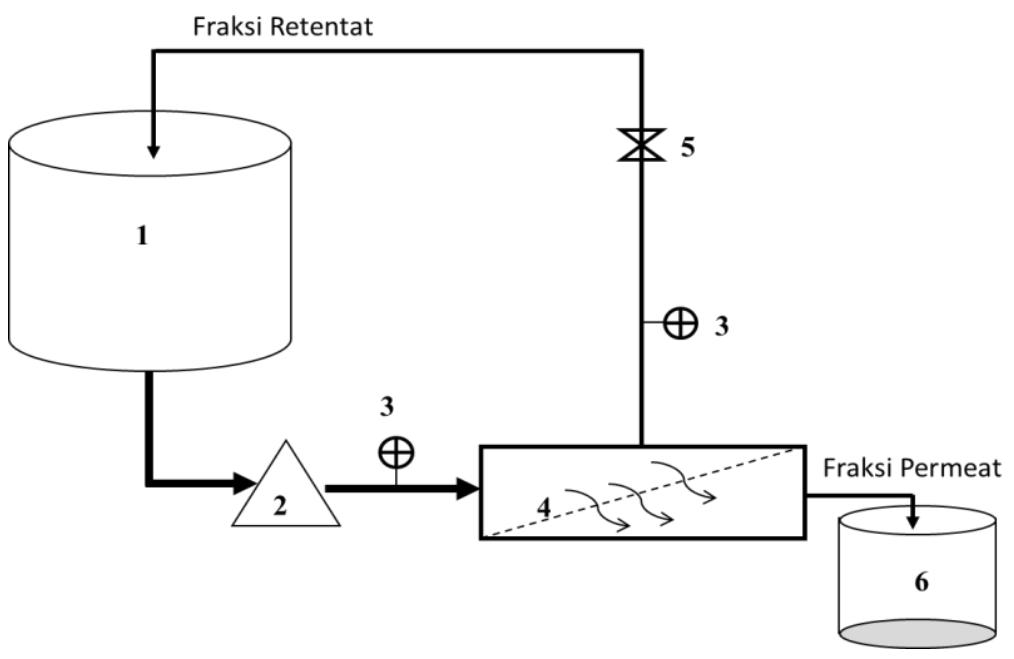

Gambar 2. Diagram skematik pengkonsentratan air rebusan pindang dengan membran ultrafiltrasi $(1=$ tangki permeat $; 2=$ pompa; $3=$ pressuregauge $; 4=$ membran ultrafiltrasi; $5=$ valve; $6=$ wadah penampungan permeat) 
Setiap 10 menit sekali, fraksi permeat hasil proses ultrafiltrasi diambil untuk dianalisis kekeruhan, $\mathrm{pH}$, total dissolved solids (TDS), chemical oxygen demand (COD), total suspended solids (TSS), salinitas, konsentrasi protein, dan lemak. Pada fraksi retentat diambil contohnya dengan jeda waktu yang sama untuk diuji konsentrasi protein, lemak, dan berat molekul proteinnya.

\section{Pencucian Membran}

Pencucian membran dilakukan setiap proses ultrafiltrasi selesai menggunakan air bersih dengan aliran terbalik (backwash). Air bersih dialirkan berlawanan melalui lubang permeat agar partikel yang menumpuk pada permukaan membran terlepas. Kemudian membran dicuci dengan cara meresirkulasikan larutan pembersih yang mengandung sabun pencuci dengan konsentrasi $5 \%$ selama \pm 30 menit. Pembilasan menggunakan air bersih dilakukan kembali setelah pencucian. Fluks membran diuji kembali menggunakan air destilasi hingga mencapai fluks semula. Jika belum mencapai fluks semula maka dilakukan proses pembersihan kembali.

\section{Prosedur Analisis}

Prosedur analisis meliputi analisis kualitas permeat, retentat, dan kinerja membran. Analisis kualitas permeat meliputi chemical oxygen demand (COD), total suspended solids (TSS), total dissolved solids (TDS), derajat keasaman $(\mathrm{pH})$, salinitas, kekeruhan, lemak, protein, dan berat molekul protein. Analisis retentat terdiri dari analisis lemak, protein, dan berat molekul protein. Analisis kinerja membran meliputi pengukuran fluks, faktor konsentrasi, dan koefisien rejeksi.

\section{Analisis Chemical Oxygen Demand (APHA, 2012)}

Analisis chemical oxygen demand
dilakukan menggunakan metode dikromat reflukstertutup. Sampel sebanyak $1 \mathrm{~mL}$ diencerkan sebanyak 100 kali dengan menambahkan akuades hingga volume $100 \mathrm{~mL}$. Sampel kemudian diaduk menggunakan vortex agar homogen. Sampel sebanyak 2,5 $\mathrm{mL}$ yang telah diencerkan ditambah dengan 1,5 mL larutan pencerna dan 3,5 mL $\mathrm{Ag}_{2} \mathrm{SO}_{4} \cdot \mathrm{H}_{2} \mathrm{SO}_{4}$. Sampel selanjutnya diaduk dengan vortex selama 1 menit dan dilakukan proses distilasi dengan kondensasi uap (refluks) pada suhu $150^{\circ} \mathrm{C}$ selama 2 jam. Sampel yang telah dingin dihitung absorbansinya pada panjang gelombang $600 \mathrm{~nm}$. Konversi nilai absorbansi menjadi nilai COD didapat melalui persamaan regresi kurva standar.

\section{Analisis Total Suspended Solids (APHA 2012)}

Pengukuran nilai total suspended solids (TSS) dilakukan dengan menyaring cairan air perebusan pindang menggunakan kertas saring yang telah diketahui bobot keringnya. Kertas saring dipasang pada pompa vakum untuk memudahkan proses penyaringan. Kertas saring yang telah berisi padatan dari air perebusan pindang dioven pada suhu $105^{\circ} \mathrm{C}$ selama 1 jam. Pendinginan dilakukan menggunakan desikator minimal 30 menit, kemudian dihitung bobotnya. Sampel sebanyak 20 $\mathrm{mL}$ disaring menggunakan pompa vakum, dilanjutkan pembilasan dengan akuades $10 \mathrm{~mL}$ sebanyak 3 kali. Kertas saring dikeringkan menggunakan oven pada suhu $105^{\circ} \mathrm{C}$ selama 1 jam dan didinginkan dengan desikator selama 30 menit. Penghitungan nilai TSS dilakukan dengan membagi selisih berat kertas saring awal dan akhir (mg) dengan jumlah sampel awal (L).

\section{Analisis Total Dissolved Solids (TDS)}

Pengukuran total dissolved solids (TDS) dilakukan menggunakan alat multimeter. Elektroda multimeter dibilas terlebih dahulu dengan akuades dan dikeringkan menggunakan tissue. Pengukuran dilakukan dengan caraelektroda multimeter dicelupkan ke dalam larutan sampel. Angka yang tertera pada layar digital dicatat dan elektroda multimeter dibilas setelah digunakan.

\section{Pengukuran Salinitas}

Pengukuran salinitas dilakukan menggunakan salinometer. Elektroda multimeter dibilas terlebih dahulu menggunakan akuades dan dikeringkan menggunakan tissue. Pengukuran dilakukan dengan cara elektroda multimeter dicelupkan ke dalam larutan sampel. Angka yang tertera pada layar digital dicatat dan elektroda multimeter dibilas setelah digunakan.

\section{Pengukuran Kekeruhan}

Kekeruhan diukur menggunakan alat turbidimeter $(H A C H, 2100 Q)$. Sampel dimasukkan kedalam kuvet sampai penuh. Sampel dikocok agar homogen dan bagian luar kuvet dilap menggunakan tissue sebelum dimasukkan kedalam alat. Angka yang tertera pada layar digital dicatat dan kuvet dibersihkan.

\section{Pengukuran Fluks (Cheryan, 1998)}

Fluks didefinisikan sebagai jumlah volume cairan yang berhasil melewati membran untuk setiap satuan luasan membran dan satuan waktu. Pengukuran fluks dilakukan setiap 5 menit dengan menghitung waktu yang dibutuhkan untuk mencapai volume $100 \mathrm{~mL}$. Nilai fluks dihitung dengan menggunakan persamaan:

$$
\text { Fluks }=\frac{\text { Jumlah volume permeat }}{\text { Luas membran } \times \text { waktu }} \times 3600
$$

\section{Pengukuran Faktor Konsentrasi (Krijgsman, 1992)}

Faktor konsentrasi didefinisikan sebagai perbandingan antara konsentrasi awal umpan $\left(\mathrm{V}_{\mathrm{F}}\right)$ dengan konsentrasi retentat $\left(\mathrm{V}_{\mathrm{R}}\right)$. Nilai faktor konsentrasi dihitung dengan persamaan: 
Faktor konsentrasi $=\frac{\text { Konsentrasi umpan }}{\text { Konsentrasi retentat }}=\mathrm{V}_{\mathrm{F}} / \mathrm{V}_{\mathrm{R}}$

$\underline{\text { Analisis Koefisien Rejeksi (Ro) (Benhabiles et al., }}$ $\underline{\text { 2013) }}$

Koefisien rejeksi $\left(\mathrm{R}_{0}\right)$ merupakan kemampuan suatu membran dalam menahan partikel terlarut tertentu. Sampling permeat untuk diuji dilakukan setiap 10 menit. Parameter koefisien rejeksi menggunakan konsentrasi pada umpan $\left(\mathrm{C}_{\mathrm{u}}\right)$ dan konsentrasi permeat $\left(\mathrm{C}_{\mathrm{p}}\right)$ kemudian dihitung dengan persamaan:

$$
\mathrm{R}_{0}=\left(1-\frac{\mathrm{Cp}}{\mathrm{Cu}}\right) \times 100
$$

\section{$\underline{\text { Analisis Protein (Bradford, 1976) }}$}

Pereaksi Bradford dibuat dengan melarutkan $20 \mathrm{mg}$ comassie briliant blueG-250 ke dalam $10 \mathrm{~mL}$ etanol $95 \%$ lalu ditambahkan $20 \mathrm{~mL}$ asam fosfat $85 \%$. Jika sudah terlarut sempurna ditambah akuades hingga 1 L dan disaring menggunakan kertas saring Whatman No. 1. Larutan standar bovine serum albumin (BSA) disiapkan pada konsentrasi 0, 200, 400, 600, 800, dan 1000 mg/L. Konsentrasi protein diukur dengan cara $0,1 \mathrm{~mL}$ larutan standar dan sampel dimasukkan ke dalam tabung reaksi. Sebanyak $5 \mathrm{~mL}$ pereaksi Bradford ditambahkan kedalam tabung reaksi dan diinkubasi selama 5-60 menit. Nilai absorbansi diukur menggunakan spectro UV-Vis RS Spectrophotometer UV-2500 pada panjang gelombang $595 \mathrm{~nm}$.

\section{Analisis Lemak (Watanabe, 1988)}

Pelarut lemak (klorometanol) disiapkan dengan mencampurkan kloroform dan metanol dengan perbandingan 2:1. Sampel sebanyak $50 \mathrm{~mL}$ dikeringkan dalam oven pada suhu $50^{\circ} \mathrm{C}$ sampai volumenya menjadi $10 \mathrm{~mL}$ lalu diekstrak dengan 50 $\mathrm{mL}$ pelarut klorometanol. Hasil diekstrak disaring dengan kertas saring dan didiamkan di corong pisah yang telah berisi $10 \mathrm{~mL} \mathrm{MgCl}_{2}$. Larutan dikocok dan didiamkan selama 24 jam agar terbentuk dua lapisan. Lapisan bawah dipisahkan dengan memutar kran pada bagian bawah corong. Sampel kemudian dikeringkan menggunakan oven pada suhu $105^{\circ} \mathrm{C}$ selam satu jam. Kadar lemak dihitung dengan cara menghitung bobot akhir cawan dikurangi bobot awal cawan.

Penentuan Berat Molekul Protein dengan Sodium Dodecyl Sulphate-Poly Acrylamide Gel Electrophoresis (SDS-PAGE) (Laemmli, 1970)

Marker yang digunakan adalah Spectra Multicolor Broad Range Protein Ladder dari Thermo Scientific. Tahapan kerja yang dilakukan dalam analisis berat molekul protein meliputi penyiapan gel pemisah dan penahan, penyiapan sampel dan loading, kondisi operasi, pewarnaan gel, dan pelunturan warna. Tahap pertama yaitu pembuatan gel $12 \%$ pemisah dan $4 \%$ gel penahan. Tahap selanjutnya yaitu preparasi sampel dengan cara membersihkan sampel dari bahan-bahan pengotor dengan sentrifuse pada kecepatan 9000 rpm selama 15 menit pada suhu $4^{\circ} \mathrm{C}$. Sebanyak 100 $\mu \mathrm{L}$ sampel yang sudah bersih dicampur dengan 25 $\mu \mathrm{L}$ buffer. Sampel kemudian disimpan dalam lemari es semalam. Tahapan selanjutnya yaitu running SDS-PAGE selama 3 jam pada arus 10-25 $\mu \mathrm{A}$, voltage konstan 60 Volt. Gel kemudian diwarnai dengan pewarna silver staining. Tahap pewarnaan diawali dengan perendaman dalam larutan fiksasi selama 12 jam pada suhu ruang sambil diagitasi secara perlahan. Gel dicuci menggunakan etanol $20 \%$ selama 20 menit sebanyak 3 kali dan dilanjutkan dibilas menggunakan akuades bebas ion selama 20 detik. Gel diinkubasi dilemari es dalam $0,1 \% \quad \mathrm{AgNO}_{3}$ selama 20 menit dan dilanjutkan pembilasan dengan air bebas ion. Gel direndam kedalam larutan developing gel hingga pewarnaan cukup, setelah pewarnaan cukup ditambahkan larutan stop solution kedalam wadah selama 5 menit. Gel dibilas menggunakan air bebas ion selama 5 menit sebanyak 3 kali. Perhitungan berat molekul dilakukan dengan memasukkan nilai Rf masingmasing pita ke dalam kurva standard.

\section{HASIL DAN PEMBAHASAN}

\section{Karakteristik Air Perebusan Pindang}

Hasil karakterisasi menunjukkan air perebusan pindang memiliki kadar organik lebih tinggi dibandingkan air cucian surimi. Hasil karakterisasi air perebusan pindang dapat dilihat pada Tabel 1.

Konsentrasi protein dalam air perebusan pindang yang terukur yaitu $631 \pm 7,07 \mathrm{mg} / \mathrm{L}$. Nilai ini lebih tinggi dibandingkan air cucian surimi yaitu $410 \pm 10 \mathrm{mg} / \mathrm{L}$ (Uju et al., 2009). Teknik proses pengolahan dan karakteristik bahan baku yang berbeda menyebabkan konsentrasi protein terlarut yang beda pada kedua hasil tersebut. Teknik perebusan dalam larutan garam mengakibatkan protein lebih banyak terlarut dalam air perebusan dibandingkan dengan hanya proses pencucian dan pemerasan yang terdapat pada proses produksi surimi.

Niamnuy et al. (2008) melaporkan bahwa konsentrasi larutan garam yang semakin tinggi mengakibatkan kelarutan protein ke dalam air perebusan semakin tinggi. Perebusan yang lama dan konsentrasi larutan garam yang semakin tinggi mengakibatkaan lebih banyak protein terutama miofibril yang terlarut dalam air garam. Kijowski dan Mast (1988) menyatakan bahwa meningkatnya kadar garam pada daging mengakibatkan penurunan stabilitas termal dari protein otot yang mengakibatkan tingginya transformasi dari miofibril dan sarkoplasma menjadi protein alkali terlarut. 
$\underline{\text { Tabel 1. Karakteristik air perebusan pindang }}$

\begin{tabular}{lrr}
\hline \multicolumn{1}{c}{ Parameter } & Air Perebusan Pindang & Air Cucian Surimi $^{\mathbf{a}}$ \\
\hline Protein (mg/L) & $631 \pm 7,07$ & $410 \pm 10$ \\
Lemak (mg/L) & $480 \pm 5,65$ & - \\
COD (g/L) & $26,73 \pm 0,47$ & $4,23 \pm 0,11$ \\
TDS (g/L) & $111 \pm 0,0$ & $1,63 \pm 0,02$ \\
TSS (mg/L) & $1.565 \pm 7,07$ & $55 \pm 3,25$ \\
Kekeruhan (NTU) & $982 \pm 2,82$ & $20 \pm 0,0$ \\
Salinitas (ppm) & $143 \pm 0,0$ & - \\
pH & $5,78 \pm 0,0$ & $6,7 \pm 0,0$ \\
\hline
\end{tabular}

Sumber :'Uju et al.(2009)

Chemical oxygen demand (COD) adalah banyaknya oksigen yang dibutuhkan untuk mengoksidasi seluruh bahan organik (yang terurai dan sukar terurai) secara kimia dengan menggunakan oksidator kuat. COD sering digunakan untuk menghitung pengotor dalam air limbah dan air alami (APHA, 2012). Nilai COD air perebusan pindang lebih tinggi yaitu 26,73 $\pm 0,47 \mathrm{~g} / \mathrm{L}$ dibandingkan air cucian surimi yaitu 4,23 $\pm 0,11$ g/L. Nilai COD yang lebih tinggi dapat disebabkan oleh kandungan protein dalam air perebusan pindang yang lebih tinggi.

Kekeruhan dalam air disebabkan oleh materi tersuspensi dan koloid yang dibedakan menjadi komponen organik dan anorganik. Kekeruhan adalah sebuah ekspresi dari properti optik yang menyebabkan cahaya akan tersebar dan diserap sebagian diteruskan (APHA, 2012). Kekeruhan air perebusan pindang lebih tinggi yaitu $982 \pm 2,82$ NTU dibandingkan air cucian surimi 20 $\pm 0,0$ NTU. Proses perebusan menyebabkan lebih banyak zat pengotor antara lain darah, protein, lemak, dan serpihan daging halus ikan terkandung dalam air perebusan sehingga meningkatkan kekeruhan.

Keasaman air adalah kemampuan kuantitatif untuk bereaksi dengan dasar yang kuat untuk pH yang ditunjuk. Keasaman memberi kontribusi untuk kekorosifan dan mempengaruhi laju reaksi kimia, spesiasi kimia, dan proses biologi (APHA, 2012). Air perebusan pindang memiliki $\mathrm{pH}$ $5,78 \pm 0,0$. Nilai tersebut lebih rendah dibandingkan air cucian surimi yaitu $6,7 \pm 0,0$. Proses pengolahan yang dialami bahan menyebabkan nilai $\mathrm{pH}$ berbedabeda.

Salinitas menggambarkan padatan total di dalam air, setelah semua karbonat dikonversi menjadi oksida, semua bromida dan iodida digantikan oleh klorida, dan semua bahan organik telah dioksidasi (Effendi, 2003). Penentuan kadar garam dilakukan dengan instrumen pengukur konduktivitas. Hal ini dikarenakan konduktivitas memiliki keakuratan yang tinggi terhadap salinitas (APHA, 2012). Salinitas air perebusan pindang lebih tinggi dibandingkan air cucian surimi yaitu 143 atau $14,3 \%$ karena pada perebusan pindang ditambahkan garam. Nilai ini berbeda dengan yang diperoleh Kuca dan Szaniawska (2009) pada air limbah industri pengolahan ikan yaitu 12,3\%. Jenis pengolahan yang berbeda menyebabkan kadar garam yang terkandung dalam air perebusan berbeda-beda.

Padatan merujuk ke dalam benda tersuspensi atau terlarut dalam air atau air limbah. Padatan dapat mempengaruhi kualitas efluen air dan merugikan. Total padatan adalah bahan residu yang tertinggal setelah sampel diuapkan dan dilanjutkan pengeringan dalam oven pada suhu tertentu. Total padatan termasuk TSS yang tidak lolos membran dengan pori $2 \mu \mathrm{m}$, dan TDS bagian yang lolos membran (APHA, 2012). TSS dan TDS air perebusan pindang memiliki nilai yang lebih tinggi dibandingkan air cucian surimi. Nilai TSS dan TDS air perebusan pindang berturut-turut $1.565 \pm 7,07$ $\mathrm{mg} / \mathrm{L}$ dan $111 \pm 0,0 \mathrm{~g} / \mathrm{L}$. Tingginya nilai TSS disebabkan oleh proses pengolahan yang menggunakan suhu tinggi sehingga banyak bagian serpihan tubuh ikan yang masuk kedalam air perebusan. Padatan tersuspensi (TSS) berkorelasi positif dengan kekeruhan. Semakin tinggi nilai kekeruhan, nilai padatan tersuspensi juga semakin tinggi. Tingginya nilai TDS disebabkan oleh tingginya kandungan garam dalam air perebusan pindang. TDS biasanya terdiri dari bahan-bahan anorganik berupa ion-ion diantaranya natrium, klorida, magnesium, kalsium, dan sulfat (Effendi 2003).

\section{Pengkonsentrasian Protein Air Perebusan Pindang}

Proses pengkonsentrasian protein air rebusan pindang menggunakan membran ultrafiltrasi $0,05 \mu \mathrm{m}$ disajikan pada Gambar 3. Selama proses ultrafilrasi, konsentrasi protein meningkat dari 631 $\mathrm{mg} / \mathrm{L}$ pada faktor konsentrasi 1 menjadi $926 \mathrm{mg} / \mathrm{L}$ pada faktor konsentrasi 6,25 atau terjadi peningkatan $47 \%$ hanya dalam waktu 40 menit. Peningkatan konsentrasi protein terjadi karena telah terjadi pemisahan terhadap kandungan air pada umpan yang menjadi permeat, sedangkan sebagian besar protein tertahan sebagai retentat yang dialirkan kembali menuju tangki umpan, sehingga konsentrasi protein pada umpan semakin tinggi.

Pada tekanan trans membran 0,5 bar, fluks permeat pada awal pengkonsentrasian $6,58 \mathrm{~L} / \mathrm{m}^{2}$ jam menjadi $2,71 \mathrm{~L} / \mathrm{m}^{2}$ jam pada menit ke-40. Penurunan fluks tajam terjadi pada saat awal pengkonsentrasian 
sampai faktor konsentrasi 1,42 atau pada menit ke10 dan setelah itu penurunan fluks menjadi kecil.

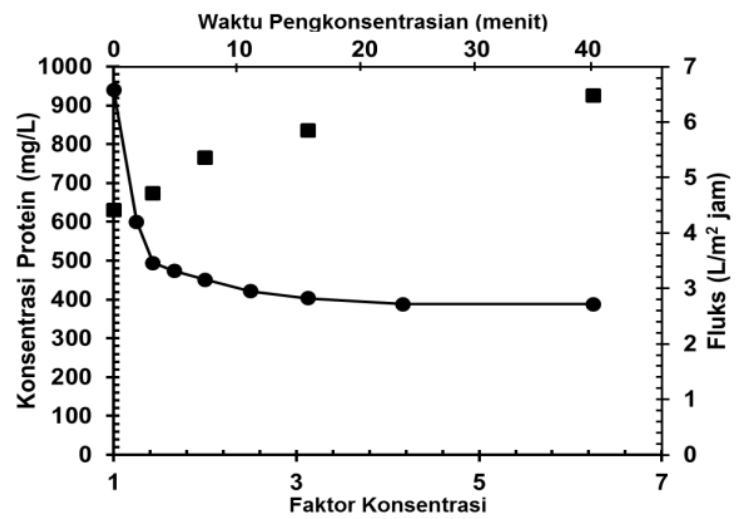

Gambar 3. Pengaruh faktor konsentrasi terhadap konsentrasi protein dan fluks permeat $(\boldsymbol{\square}=$ Konsetrasi protein, dan $\bullet=$ Fluks)

Proses penurunan fluks tersebut lebih cepat sepeerti yang dilaporkan Chollangi dan Hossain (2007) pada proses pemisahan protein dan laktosa dari limbah industry susu. Penurunan awal yang cepat dapat disebabkan oleh akumulasi molekul pada permukaan membran. Penurunan fluks tersebut menunjukkan bahwa terjadi lapisan fouling pada permukaan membran yang semakin lama semakin menebal. Hal tersebut menyebabkan meningkatkatnya resistensi terhadap transfer massa yang juga ditandai menurunnya fluks permeat (Chabeaud et al., 2009). Jika dibandingkan hasil penelitian sebelumnya penurunan fluks ini masih lebih rendah dengan yang dilaporkan oleh Sotoft et al. (2015) pada recovery protein marinade menggunakan membran ultrafiltrasi $50 \mathrm{kDa}$ yang memperoleh penurunan fluks $68,42 \%$.

Koefisien rejeksi protein mengalami peningkatan selama pengkonsentrasian (Gambar 4). Hal tersebut disebabkan oleh kadar protein yang semakin meningkat seiring dengan fungsi waktu proses pengkonsentrasian seperti yang disajikan dan dibahas pada Gambar 3. Peningkatan nilai koefisien rejeksi disebabkan sebagian besar protein menumpuk pada permukaan membran dan akan meningkatkan koefisien rejeksi seperti yang dilaporkan (Goosen et al., 2011). Menurut Cheryan (1998) makromolekul seperti protein akan terejeksi dan menumpuk serta akan menutupi permukaan membran mikrofiltrasi ultrafiltrasi serta membentuk lapisan gel atau cake dan proses ini membuktikan atau terjadinya fouling pada permukaan pada membran.

Kisaran nilai rejeksi protein 41,2-55,7\% masih lebih rendah dengan yang dilaporkan Benhabiles et al. (2013) yang memperoleh nilai rejeksi protein hingga $97 \%$ pada recovery protein limbah deproteinisasi kitin menggunakan membran ultrafiltrasi $0,05 \mu \mathrm{m}$. Perbedaan hasil ini dipengaruhi oleh jenis membran dan sampel yang digunakan. Besar molekul protein dalam setiap sampel berbedabeda tergantung jenis sampel yang digunakan. Protein dalam air perebusan pindang diduga telah mengalami perubahan berat molekul sehingga beratmolekul proteinnya menjadi kecil akibat pemanasan selama \pm 6 jam. Elagamy (2000) melaporkan bahwa suhu dan waktu pemanasan mempengaruhi profil protein. Perebusan pada suhu tinggi menyebabkan berat molekul protein menjadi kecil. Firlianty et al. (2014) juga melaporkan bahwa pemanasan dapat menyebabkan pemecahan protein

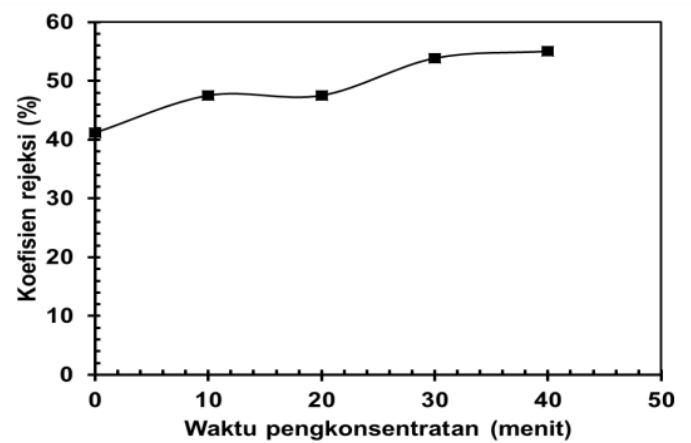

Gambar 4. Koefisien rejeksi protein selama pengkonsentrasian

\section{Karakteristik Permeat}

Penyaringan air perebusan pindang dengan membran ultrafiltrasi menghasilkan penurunan nilai COD, TSS, kekeruhan, protein, dan lemak dalam fraksi permeatnya (Tabel 2). Tingkat penurunan (reduksi) yang sangat tinggi diperoleh pada molekul yang memiliki ukuran besar yaitu direpresentatifkan pada parameter kekeruhan TSS dan lemak dengan nilai lebih dari $90 \%$.

Tabel 2. Karakteristik permeat hasil ultrafiltrasi

\begin{tabular}{|c|c|c|c|c|c|c|}
\hline \multirow{2}{*}{ Parameter } & \multicolumn{5}{|c|}{ Waktu Pengkosentratan (menit) } & \multirow{2}{*}{$\begin{array}{c}\text { Reduksi } \\
(\%)\end{array}$} \\
\hline & $\mathbf{0}$ & 10 & 20 & 30 & 40 & \\
\hline Kekeruhan (NTU) & $54,5 \pm 0,1$ & $5,17 \pm 0,1$ & $5,17 \pm 0,0$ & $5,08 \pm 0,0$ & $3,17 \pm 0,0$ & 99,67 \\
\hline $\mathrm{TSS}(\mathrm{mg} / \mathrm{L})$ & $120 \pm 7$ & $92,5 \pm 4$ & $90 \pm 0,0$ & $82,5 \pm 4$ & $82,5 \pm 3,5$ & 94,72 \\
\hline Lemak (mg/L) & $43 \pm 0,1$ & - & - & - & $34 \pm 0,2$ & 92,91 \\
\hline $\mathrm{COD}(\mathrm{g} / \mathrm{L})$ & $21,1 \pm 0,5$ & $19,4 \pm 0,0$ & $19,1 \pm 0,5$ & $16,9 \pm 0,2$ & $16,2 \pm 1,2$ & 39,27 \\
\hline $\operatorname{TDS}(\mathrm{g} / \mathrm{L})$ & $108 \pm 0,0$ & $107 \pm 0,0$ & $106,5 \pm 0,0$ & $106,5 \pm 0,0$ & $106,5 \pm 0,0$ & 4,05 \\
\hline Salinitas(ppm) & $139 \pm 0,0$ & $138 \pm 0,0$ & $138 \pm 0,0$ & $137 \pm 0,0$ & $137 \pm 0,0$ & 4,19 \\
\hline
\end{tabular}

apada menit ke-40 dibandingkan dengan sampel awal. 
Kekeruhan permeat hasil ultrafiltrasi mengalami penurunan $99,67 \%$, yaitu dari $982 \pm 2,82$ NTU pada sampel awal menjadi 3,17 $\pm 0,04$ NTU pada menit ke-40. Penurunan tingkat kekeruhan ini secara kasat mata dapat diamati dengan mudah (Gambar 5). Kekeruhan dalam air perebusan pindang diduga disebabkan oleh bahan-bahan tersuspensi dan koloid yang sulit mengendap. Penurunan kekeruhan yang tinggi dengan diterapkannya ultrafiltrasi disebabkan oleh banyaknya tersuspensi dan koloid tersebut serta pengotor lainnya seperti serpihan daging pada sampel awal tidak dapat melewati poripori membrane sehingga dihasilkan warna permeat yang lebih jernih. Menurut Cheryan (1998) membran ultrafiltrasi tepat untuk pemisahan molekul yang cukup besar misal polimer alam, pati, protein, material koloid pada larutan. Sebagian besar partikel-partikel penyebab kekeruhan tidak dapat melewati membran ultrafiltrasi.

Kandungan padatan tersuspensi (TSS) mengalami penurunan hingga 94,72\% dari $1.565 \pm$ $7,07 \mathrm{mg} / \mathrm{L}$ menjadi $82,5 \pm 3,53 \mathrm{mg} / \mathrm{L}$ pada menit ke40. Hasil ini mendekati nilai yang dilaporkan oleh Gringer et al. (2015) yang memperoleh nilai penurunan TSS 95\% pada recovery biomolekul dari marinade menggunakan membran keramik. Hal ini menunjukkan bahwa ultrafiltrasi memberikan pengaruh yang besar terhadap partikel-partikel tersuspensi pada air perebusan pindang yaitu serpihan daging, darah, sisik, dan lain-lain.

Salinitas dan padatan terlarut (TDS) permeat ultrafiltrasi masing-masing mengalami penurunan $4,19 \%$ dan $4,05 \%$ menjadi $137 \pm 0$ dan 106,5 \pm 0,0 g/L. Gringer et al. (2015) melaporkan bahwa kadar garam pada proses ultrafiltrasi tidak mengalami perubahan yang signifikan yaitu $0,7 \%$. Menurut Cheryan (1998) membran ultrafiltrasi masih dapat meloloskan molekul kecil antara lain garam, berbeda dengan membran reverse osmosis yang dapat menahan molekul garam. Kandungan garam yang tinggi ini merupakan suatu kelebihan dalam proses pengolahan air perebusan pindang, karena air hasil pengolahan dapat digunakan kembali untuk perebusan tanpa dilakukan penambahan garam.
Analisis Berat Molekul Protein
Elektroforesis merupakan teknik untuk memisahkan molekul berdasarkan muatan dan berat molekul (Bintang, 2010). Jenis elektroforesis yang digunakan pada penelitian ini adalah SDS-PAGE yang menggunakan gel yang tersusun dari poliakrilamida. Metode ini biasa digunakan untuk mengestimasi bobot molekul protein, selain itu biasanya digunakan untuk memantau pemurnian protein (Wilson dan Walker, 2010). Hasil elektroforegram SDS-PAGE sampel air perebusan pindang dapat dilihat pada Gambar 6 .
Hasil uji SDS-PAGE menunjukkan bahwa estimasi berat molekul protein yang dominan pada sampel air perebusan pindang adalah $33,45 \mathrm{kDa}$, selain itu juga terdapat protein lain dengan berat molekul 13,79 kDa, 17,31 kDa, 55,14 kDa, 70,79 $\mathrm{kDa}, 139,92 \mathrm{kDa}$, dan $183,76 \mathrm{kDa}$. Pita-pita protein ini diduga merupakan hasil fragmentasi dari protein besar daging ikan menjadi protein yang berukuran lebih kecil. Sotoft et al. (2015) menjelaskan bahwa proses proteolitik dapat memecah protein molekul besar daging ikan diantaranya aktin $(42 \mathrm{kDa})$ dan miosin $(200 \mathrm{kDa})$ menjadi protein berukuran lebih kecil. Pemanasan merupakan salah satu contoh proses proteolitik. Terdapat perbedaan profil protein pada sampel awal air perebusan pindang, retentat, dan permeat. Estimasi berat melekul protein pada permeat tinggal menyisakan protein dengan berat molekul 13,79 kDa, 17,31 kDa, 33,45 kDa, 55,14 $\mathrm{kDa}$, dan $70,79 \mathrm{kDa}$. Profil protein pada permeat tidak ditemukan pita protein dengan berat molekul 139,92 kDa dan 183,76 kDa. Berkurangnya jumlah pita protein pada permeat menunjukkan protein dengan berat molekul $139,92 \mathrm{kDa}$ dan $183,76 \mathrm{kDa}$ tidak lolos melewati membran ultrafiltrasi yang digunakan.

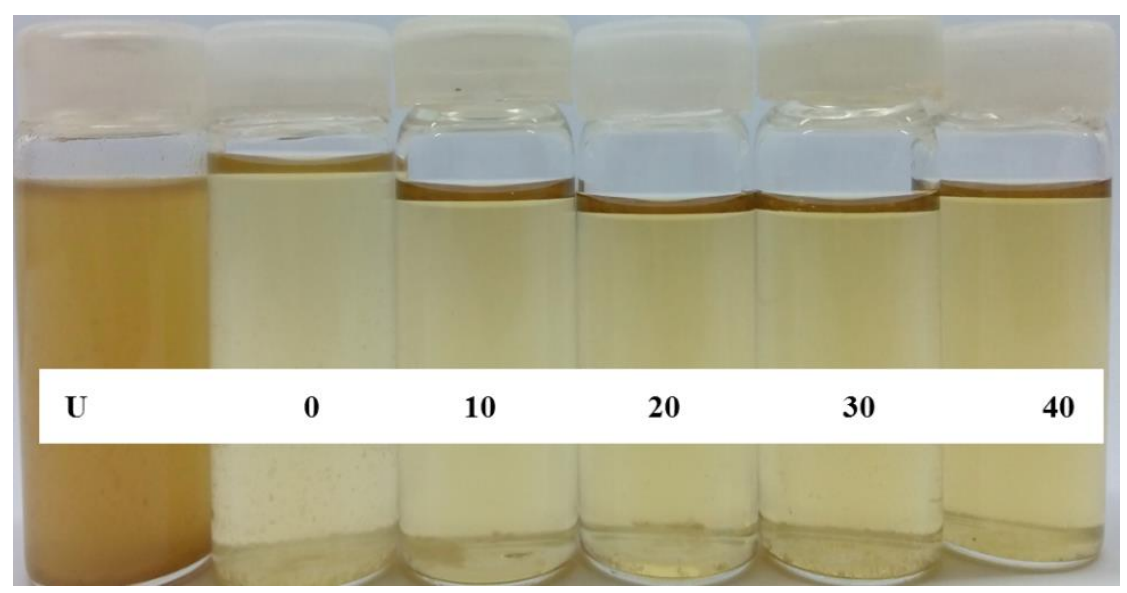

Gambar 5. Perbandingan umpan dan permeat setiap waktu. (U= umpan yaitu sebelum difiltrasi, dan angka 0-40 menunjukkan waktu sampling pada permeat) 


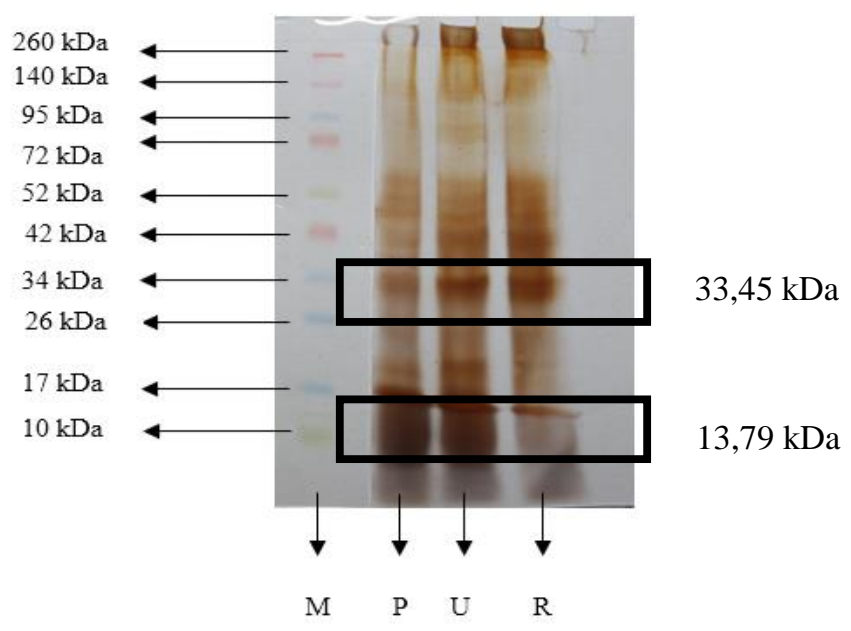

Gambar 6. Hasil elektroforegram SDS-PAGE air perebusan pindang ( $\mathrm{M}=$ Marker, $\mathrm{P}=$ Permeat menit ke-40, $\mathrm{U}=$ Umpan, dan $\mathrm{R}=$ Retentat)

Hal tersebut terjadi karena membran yang digunakan dengan rata-rata MWCO $40 \mathrm{kDa}$. Profil protein pada retentat hampir sama seperti sampel awal air perebusan pindang, meskipun terdapat perbedaan ketebalan pita proteinnya. Protein dengan berat prolekul $183,76 \mathrm{kDa}$ lebih banyak pada retentat ditandai dengan pita protein yang lebih tebal. Perbedaan lainnya yaitu muncul pita protein dengan berat molekul 171,66 kDa yang tidak terdapat pada sampel awal.

Protein dengan berat molekul besar, yakni $183,76 \mathrm{kDa}$ dan $33,45 \mathrm{kDa}$ jumlahnya meningkat pada retentat dibandingkan pada umpan. Pita protein dengan berat molekul 13,79 $\mathrm{kDa}$ pada retentat yang jauh lebih tipis dibandingkan umpan. Hal ini dapat disebabkan oleh sebagian besar protein dengan berat molekul rendah sudah lolos melewati membran ultrafiltrasi sehingga jumlahnya menurun pada retentat. Menurut Cheryan (1998) dalam proses ultrafiltrasi perbedaan tekanan yang melintasi membran ultrafiltrasi akan memaksa pelarut dan molekul yang lebih kecil melewati pori-pori membran, sementara molekul yang lebih besar akan ditahan dan dialirkan sebagai retentat.

\section{KESIMPULAN DAN SARAN}

\section{Kesimpulan}

Membran ultrafiltrasi dengan rata-rata ukuran pori $0,05 \mu \mathrm{m}$ dapat digunakan pada recovery protein air perebusan pindang dengan nilai rejeksi hingga 55\%. Pengkonsentrasian mengakibatkan konsentrasi protein meningkat $46,75 \%$. Berat molekul protein yang dominan adalah $33,45 \mathrm{kDa}$. Permeat yang dihasilkan memungkinkan untuk digunakan kembali pada proses perebusan pindang.

\section{Saran}

Untuk mengurangi kandungan besar fouling sebaiknya digunakan proses prefiltrasi. Penggunaan membran ultrafiltrasi dengan ukuran pori lebih kecil diharapkan meningkatkan nilai rejeksi protein. Perlu penelitian lanjutan untuk memanfaatkan konsentrat protein yang telah dihasilkan.

\section{UCAPAN TERIMA KASIH}

Sebagian penelitian ini didanai oleh Kemenristek DIKTI melalui skema Program Kreativitas Mahasiswa (PKM) tahun 2015.

\section{DAFTAR PUSTAKA}

[AOAC] Association of Official Analytical Chemists. 1995. Official Methods of Analysis of The Association of Official Analytical of Chemists. Arlington (US): The Association of Official Analytical Chemists, Inc.

[APHA] American Public Health Association. 2012. Standar Methods for Examination of Water and Waste Water. Washington DC (US): American Public Health Association.

Benhabiles MS, Abdi N, Droviche N, Lounici H, Pauss A, Gosen MFA, Mameri N. 2013. Protein recovery by ultrafiltration during isolation of chitin from shrimp shells Parapenaeus longirostris. Food Hydrocolloids. 32: 28-34.

Bintang M. 2010. Biokimia - Teknik Penelitian. Jakarta (ID): Erlangga.

Bradford MM. 1976. A rapid and sensitive method for the quantitation of microgram quantities of protein utilizing the principle of protein dye binding. Analysis Biochemistry. 72: 248254.

Chabeaud L, Vandonjon V, Bourceau P, Jaouen P, Guerart F. 2009. Fractionation by ultrafiltration of saithe protein hydrolysate (Pollachius virens): effect of material and molecular weight cut-off on the membrane performances. Journal of Food Engineering. 91: 408-414. 
Cheryan M. $1998 . \quad$ Ultrafiltration and Microfiltration Handbook. Lancaster (US): Technomic Publishing Co. Inc.

Chollangi A dan Hossain M. 2007. Separation of proteins and lactose from dairy wastewater. Chemical Engineering Processes. 46: 398404.

Dumay J, Radier S, Barnathan G, Berge J, Jaouen P. 2008. Recovery of valuable soluble compounds from washing waters generated during smal fatty pelagic surimi processing by membrane processes. Environmental Technology. 29: 451-461.

Effendi H. 2003. Telaah Kualitas Air bagi Pengelolaan Sumber Daya dan Lingkungan Perairan. Yogyakarta (ID): Kanisius.

Elagamy EI. 2000. Effect of heat treatment on camel milk proteins with respect to antimicrobial factors: a comparison with cows' and buffalo milk proteins. Food Chemistry. 68: 227-232.

Firlianty, Suprayitno E, Hardoko, Nursyam H. 2014. Protein profile and amino acid profile of vacuum drying and freeze-drying of family channidae collected from central kalimantan, indonesia. International Journal of Biosciences. 5(8): 75-83.

Fitriyani RH, Susilo B, dan Komar N. 2013. Studi pengaruh penambahan air dan suhu pemanasan terhadap viskositas petis ikan. Jurnal Keteknikan Pertanian Tropis dan Biosistem. 1(2): 29-34.

Guo X, Zhang Z, Fang L, Su L. 2009. Study on ultrafiltration for surface water by polyvinylchloride hollow fiber membrane. Desalination. 238(1-3): 183-191.

GoosenMFA, SablaniS, Dal-SinM, Wilf M. 2011. Effect ofcyclicchanges intemperature and pressure on permeation properties of composite polyamideseawater reverse osmosis membranes. Separation Science and Technology. 46:14-26.

Gringer N, Hosseini SV, Svendsen T, Undeland I, Christensen ML, Baron CP. 2015. Recovery of biomolecules from marinated herring (Clupea harengus) brine using ultrafiltration through ceramic membranes. LWT-Food Science and Technology. 43:1-7.

Kijowski JM dan Mast MGE. 1988. Effect of sodium chloride and phosphates on the thermal properties of chicken meat protein. Journal of Food Science. 53:367-370.

[KKP] Kementrian Kelautan dan Perikanan. 2016. Direktorat Jenderal Penguatan Daya Saing Produk 2015. Jakarta (ID): Kementrian Kelautan dan Perikanan.

Krijgsman J. 1992. Product Recovery in Bioprocess Technology. Oxford (GB): ButterworthHeinemann.
Kuca M dan Szaniawska D. 2009. Application of microfiltration and ceramic membranes for treatment of salted aqueous effluents from fish processing. Desalination. 241: 227-235.

Kumar M dan Lawler J. 2014. Preparation and characterization of negatively charged organic-inorganic hybrid ultrafiltration membranes for protein separation. Separation and Purification Technology. 130: 112-123.

Kurinomaru T, Maruyama T, Izaki S, Handa K, Kimoto T, Shiraki K. 2014. Protein-poly (amino acid) complex presipitation for highconcentration protein formulation. Journal of Pharmaceutical Sciences. 103(8): 2248-2254.

Laemmli UK. 1970. Cleavage of structural proteins during the assembly of the head of bacteriophage T4. Nature. 227: 680-685.

Masse A, Thi HN, Legentilhomme, Jaouen P. 2011. Dead-end and tangential ultrafiltration of natural salted water: influence operating parameters on specific energy consumption. Journal of Membrane Science. 380: 192-198.

Niamnuy C, Devahastin S, dan Soponronnarit S. 2008. Changes in protein compositions and their effects on physical changes of shrimp during boiling in salt solution. Food Chemistry. 108: 165-175.

Schuck P, Jeantet R, Tanguy G, Mejean S, Gac A, Lefebvre T, Labussiere E, Martineaur C. 2015. Energy consumption in the processing of dairy and feed powders by evaporation and drying. Drying Technology. 33: 176-184.

Shukoor MI, Natalio F, Tahir MN, Ksenofontov V, Therese HA, Theato P, Schroder HC, Muller WEG, Tremel W. 2007. Superparamagnetic $\mathrm{Fe}_{2} \mathrm{O}_{3}$ nanoparticles with tailored functionality for protein separation. Chemistry Community. 4677-4679.

Sotoft LF, Lizarazu JM, Parjilolaei BR, Karring H, Christensen KV. 2015. Membrane fractionation of herring marinade for separation and recovery of fats, proteins, amino acids, salt, acetic acid, and water. Journal of Food Engineering. 158: 39-47.

Uju, Tati N, Bustami I, Wini T, Maglory S. 2009. Karakterisasi dan recovery protein dari air cucian minced fish dengan membran reverse osmosis. Jurnal Pengolahan Hasil Perikanan Indonesia. 12(2): 115-127.

Watanabe T. 1988. Fish Nutrition and Marinculture. JICA Text Book. The General Aquaculture Course Departement of Aquaculture Biosciences. Tokyo (JP): Tokyo University of Fisheries.

Wilson K dan Walker J. 2010. Principlesand Techniques of Biochemistry and Molecular Biology. Ed ke-7. Hlm 403-465. London (UK): Cambridge University. 